\title{
British Clocks in Eighteenth-Century China: Presents, Tribute, or Trade?
}

\author{
Roger SMITH ${ }^{1}$
}

(Independent Historian, UK)

\begin{abstract}
It is commonly believed that most European clocks that reached China before the nineteenth century were sent to the emperor as diplomatic presents from European rulers, or were given to Chinese officials by European merchants in attempts to improve trading conditions. Although such presents had been given in earlier times, British records show that, by the eighteenth century when the export of clocks to China reached its height, most clocks, including the finest, reached China as private trade goods. Once in Canton (Guangzhou), the best clocks were bought by local Chinese officials for inclusion in their annual tribute to the emperor and senior members of the government in Beijing, where many of these clocks survive in the former imperial collection.

Keywords: Britain, China, eighteenth century, trade, clocks, presents, tribute, Emperor Qianlong, Macartney Embassy
\end{abstract}

$T^{t}$ is well known that the earliest European clocks ${ }^{2}$ reached China and other parts of South and East Asia in the sixteenth century as presents to local rulers. Catholic missionaries and especially Jesuits were particularly active in using clocks to gain permission to proselytize. St. Francis Xavier took a clock to Japan as early as 1549, while Matteo Ricci took a clock to Portuguese-controlled Macao in 1582, and in the following years gave several clocks to Chinese officials. Famously, this culminated in an invitation for Ricci to visit Beijing in 1601 to present two striking clocks to Emperor Wanli, and he remained in Beijing to maintain the clocks and advise the emperor on astronomy and other aspects of European science. This role was inherited by Ricci's successors in the China mission, and they and the European rulers who supported them presented further European clocks to later emperors, while at the end of the

Received: April 30, 2020. Revised: September 4, 2020.

1 Research interests: International aspects of the European clock and watch trade in the eighteenth century. These include the role of migration in the transfer of new technology and styles, and the nature and size of exports from Europe to other parts of the world, and especially to China. Email: smith_roger@btinternet.com

2 "Clock" in this article includes any object containing clockwork unless stated otherwise. 
seventeenth century Emperor Kangxi (r. 1661-1722) set up an Imperial Clock Workshop in the precincts of the Forbidden City to make and repair such clocks under missionary supervision.

The Jesuit missionaries were not the only source of Western clocks, and as other European countries established contact with China in the seventeenth century, they gave presents, often including clocks, to local officials or even to the emperor himself, in the hope of facilitating trade. For example, the Dutch, as a leading European trading nation, sometimes sent clocks to the Chinese emperor in the later seventeenth century (Jamieson 1883). This tradition of present-giving continued into the eighteenth century, by which time trade between Europe and China had increased enormously. However, formal contact between European states and Chinese rulers remained rare until the end of the century, so the opportunity for making diplomatic gifts was severely limited. Nevertheless, the imperial collection was said in 1736 to hold over four thousand Western clocks, watches, and related objects (including mechanical music and scientific instruments) (Pelliot 1920-1921; Bonnant 1960); and by the end of the century, the first British ambassador to reach Beijing was told in 1793 that the emperor's collection of clocks and curiosities was worth more than $£ 2,000,000$ (Cranmer-Byng 1962, 261). Of these, well over one thousand clocks still survive in the Palace Museum, while some are now in other collections. Evidently, few of these clocks can have been directly presented by European states, or even by their merchant companies, yet that is the story still believed and circulated by collectors, salerooms, and dealers, and even by some museums. This short paper aims to explain how this common misunderstanding arose, and how most of these distinctive, mainly British, clocks really entered the imperial collection. ${ }^{3}$

Romantic tales identifying such clocks as diplomatic gifts have been current since they were first made, being used by the makers to create publicity and increase the appeal of their clocks for potential customers. As early as 1731, a musical clock made by Christopher Pinchbeck of London, and said to be valued at over $£ 1000$, was exported to the East Indies, allegedly intended as "a present to the Emperor of China," though from whom is not stated (Daily Advertiser 1731). By the 1760s-1770s, James Cox (ca. 17231800), who was then the leading London producer of such clocks and owner of a museum where they were exhibited to the paying public, frequently placed such stories in the London newspapers and other publications (Smith 2000). He sometimes did this anonymously, as in 1766 when the newspapers published a description of two curious clocks made by "English artists" in the form of chariots, and said to be "intended as a

3 A valuable English-language study of these distinctive clocks, based on the Palace Museum collection, can be found in Pagani (2001). 
present from the East India Company to the Emperor of China." An apparently identical chariot signed by Cox is now in the Metropolitan Museum, New York, whose website repeats the story of it being presented to Emperor Qianlong (London Evening Post 1766). Although the newspaper did not name Cox as the maker, he presumably provided the story in the expectation of being identified. Indeed, in other notices he was happy to provide his name but left other parts of the story vague. He might avoid naming a specific recipient, as in 1769 when some of his "curious clocks" and "rich pieces of machinery" were exported on a British East India Company (EIC) ship "as a present to some great men in the Eastern parts of the world" (Whitehall Evening Post 1769). Other notices named both Cox and the recipient but without specifying that the clock was a present, as in 1772, when another example of Cox's "Chronoscope" exhibited in his Spring Gardens Museum was said to grace "the palace of the Emperor of China, at Pekin" (Anonymous 1772a, 13).

Similar publicity tactics continued to be used for such clocks for many years. In 1806, a former French merchant and ship's commander described a magnificent clock he had seen in Canton in 1787, which had cost $£ 10,000$ in London, and which he believed was a present from the EIC to the emperor (Blancard 1806, 416). ${ }^{4}$ Taken together, such stories gave the clear impression that clocks were regularly being sent from London as presents to the emperor of China and other "great men" in the East Indies. This would have seemed highly appropriate for the larger musical clocks and automata, which were very expensive and looked quite different from the clocks usually made for European customers. Similar stories were revived in the later nineteenth century, when clocks taken from the imperial palaces by Western troops were brought back to Europe, and they are still not dead in the popular mind.

However, not everyone was convinced by these stories. As long ago as 1933, Simon Harcourt-Smith stated in the introduction to his catalogue of European clocks in the Palace Museum that "Contrary to popular belief, hardly any of the pieces herein described [. . .] can have been presents from foreign governments to the Court of China." After an oversimplified account of how Cox's clocks reached China, he noted that "the others were undoubtedly acquired through the intermedians [sic] of the East India Company at Canton" 5 (Harcourt-Smith 1933, 2). Although Harcourt-Smith did not provide his evidence, it was readily available for historians to find. Cox himself, in one of his later publications, revealed the way in which some of his clocks had actually reached the emperor. Listing the clocks in his museum to be sold by lottery in 1775, he

4 The date suggests an association with Cathcart's abortive embassy of 1787-1788, but that never reached China, and there were no valuable clocks among its presents, though there were some watches to give to Chinese officials.

5 The reference to the EIC being the intermediary at Canton was not strictly correct, since clocks were private trade goods. 
noted that a pair of goat clocks similar to those in the museum had been "purchased at a great price in Canton, from whence they were sent with the presents annually made to the Court of Pekin from that province" (Cox 1775). A clock of this type is still in the Palace Museum, Beijing, and another is shown in Figure 1. More generally, Cox's catalogues and the notices he placed in the London newspapers continually stressed the commercial value of his activities in exporting clocks to Asia. To quote from one of these notices, "His merchandize has been vended [sold] from the gulf of Persia to the extremity of China, and northward among the Tartar nations" (Anonymous 1772b).

However, it is not necessary to rely on the sometimes contradictory statements of a single producer and exporter such as Cox to show that most of the clocks that entered the imperial collection in the eighteenth century could not have been diplomatic gifts. On the evidence of surviving clocks in the Palace Museum, most were from Britain, but no British embassy reached China until 1793, when it brought numerous presents that will be discussed below. An alternative source of presents might have been the EIC, which dominated trade between Europe and the East Indies at this time. It would certainly have been prepared to give valuable presents to achieve its objectives of persuading the Chinese government to improve the conditions under which it had to trade, such as the restriction to Canton and to the government-controlled monopoly of Hong merchants. Many of the EIC's records survive, and a surprising amount is known about its activities, including presents to foreign rulers and officials. Since the finest clocks would have been very expensive (up to $£ 2000$ or even more), a decision to give such presents to the emperor or senior officials in China would certainly have been recorded.

Smaller presents given by the commanders and supercargoes of individual EIC ships to secure the goodwill of local officials in Canton were not always recorded, but would not have included expensive clocks: for example, the presents given to local officials in 1721 included no clocks and only one silver watch. Three years later there was a curious occurrence when the company's merchants in Canton were forced to subsidize the purchase of a clock that the chief customs commissioner (known to the British as the Hoppo) wanted to buy for the emperor. He refused to pay the price of 1400 taels of silver (£466) set by its private importer, and stopped the loading of the company's ships until he got it. That forced the British merchants to buy it from the owner at the full price, and sell it at a loss to the Hoppo for only 960 taels (£320). However, although it involved the EIC in some expense, this clock was clearly not a present to the Hoppo, and still less to the emperor, assuming he ultimately received it. ${ }^{6}$

The EIC's directors in London were not involved in such local decisions, but they sometimes decided to give larger presents to gain important trading objectives. One of

6 British Library India Office Records (BL IOR), G/12/22:7, 9; G/12/24, January 10, 1724 (NS): 87-89. 


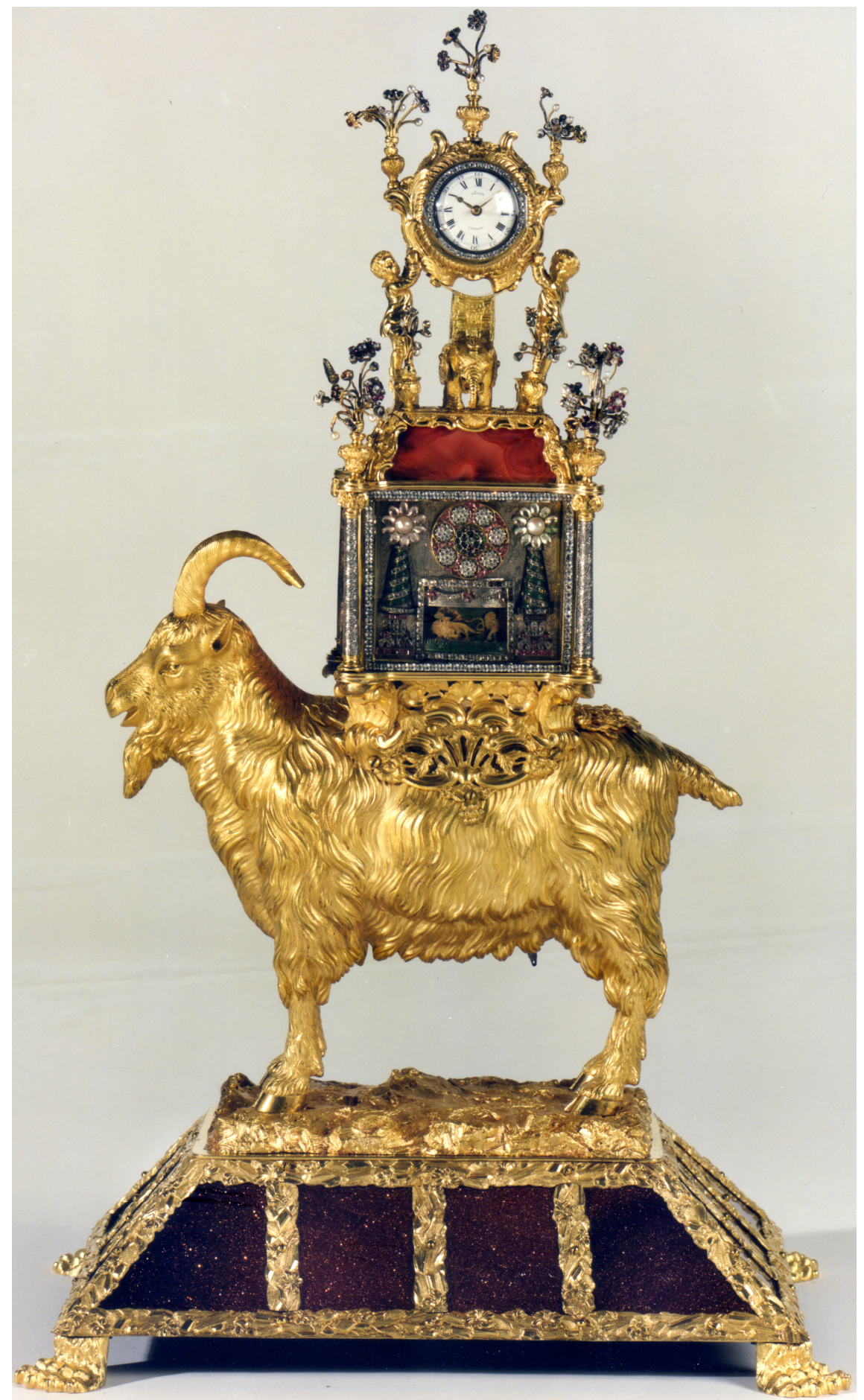

Figure 1: Goat musical clock with automata, signed James Cox, London, ca. 1770, height $58 \mathrm{~cm}$. Courtesy of Partridge, London. 
the company's objectives was to establish trading activities further north in China, where it might be easier to sell the fine woolen cloth which was then Britain's main export. In 1757 it sent a present to a senior mandarin in Ningbo, where it hoped to establish a new base, but this was not a valuable clock but a diamond ring valued at

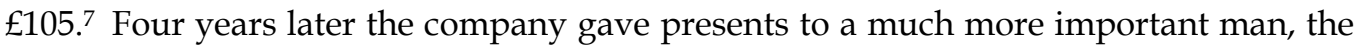
provincial viceroy, in an attempt to settle major grievances at Canton. Even so, the presents cost only $£ 368$ in total, including two clocks with a combined value of only $£ 176$; and even these modest presents were refused by the viceroy, perhaps for fear that he might be accused of receiving bribes. ${ }^{8}$ (That was the reason given by a later viceroy in the reign of Emperor Jiaqing, when he accepted only a part of the "considerable presents" he was offered..$^{9}$ )

It is therefore clear from the EIC's own records that no expensive clocks were given by the company to the Chinese emperor in this period, and few if any to local officials who might have passed them on to the emperor. This was not a matter of the company being parsimonious, since in the very different political circumstances of India it was prepared to give much more substantial presents to local rulers. For example, in 1757 it gave the Nawab of Bengal presents costing some $£ 1650$ in total, including a musical clock in a "Chinese Temple" case valued at $£ 300$. In 1764 the company gave the Nawab of Arcot an even more impressive gift of a "temple enriched with diamonds and precious stones" costing $£ 3000 .{ }^{10}$ That was equal to the cost of an important clock, but there is no evidence that the temple had a mechanical movement, and it was probably a piece of jewelry, using much more valuable stones than are found on clocks.

It is significant that these expensive presents were for India rather than China. There were in fact important reasons of protocol why the EIC sent few large presents to China. The sensitivity of the viceroys at Canton to accusations of bribery has already been mentioned, but it was even more difficult for a foreign trading company to give presents to the emperor himself. When the company considered giving a present of some woolen cloth to the emperor in 1759, it was advised by senior Chinese officials that "no one but ambassadors are allowed to make presents [to the emperor] \& that in the name of their king."11 In other words, foreigners could only give presents to the emperor through a formal government-to-government embassy to Beijing.

Although only one British diplomatic embassy actually reached China in the eighteenth century, an earlier embassy had been sent in 1788, but had to be abandoned when the ambassador, Colonel Cathcart, died before reaching China. In preparing for

7 BL IOR, B/74, December 7, 1757:565.

8 BL IOR, B/76, October 22, 1760:220 for the decision. The values are noted in Morse (1926-1929, 106).

9 BL IOR, G/12/178, November 6, 1811:80-81.

10 BL IOR, D/106, Memoranda 1757 (n.p.); B/80, November 14, 1764:269.

11 BL IOR, D/108, Memoranda 1760 (n.p.), memo received September 25, 1760. 
Cathcart's embassy, the EIC had advised the British government that there were no presents that could be offered to the emperor which would be acceptable to him, and the ambassador simply took a formal letter from the king placed in a gold box "more as a mark of attention than in the light of a present."12 However, other presents with a total value of $£ 4000$ were taken to give to senior officials who could assist the embassy in China, including ten watches with the modest value of $£ 374$, but apparently no clocks.

A few years later, Macartney's embassy of 1793 adopted a different approach, spending over $£ 13,000$ on carefully chosen gifts for the emperor. Some confusion over the nature of these gifts - or tribute, as the emperor and his officials insisted on calling them-may have strengthened the false impression that most of the Western clocks collected by Emperor Qianlong arrived as diplomatic gifts like these. Given the emperor's well-known interest in clocks and the fact that Macartney represented the country from which most of these clocks came, it might be expected that they would feature strongly among the presents. Indeed, that appears to be confirmed by the emperor's reaction to these presents, including his impatience with the suggestion that the scientific instruments brought by the British embassy were too delicate to be moved after being set up by the embassy's craftsmen. As he observed when reprimanding the mandarin escorting the embassy:

Since Zhengrui [ . . . ] has not held the office of Superintendent of the Canton Customs, his acquaintance with Western clocks and other articles is not extensive and he is inexperienced in such matters. Now the Tribute Envoy [Macartney] has seen that there are people in the Celestial Empire who are versed in astronomy, geography and clock repairing and are now helping alongside those who are setting up the articles, he can no longer boast that he alone has got the secret. (A court letter of August 28, 1793 [quoted in Singer 1992, 46])

The emperor's response seems to have misled some modern Chinese scholars into believing that the "clocks" presented by the embassy were comparable with those he already owned in large numbers, but whereas Qianlong seems to have regarded most clockwork articles as objects of amusement and without practical use, these scholars have tended to see them all as representing advanced European technology - see for example Zhang and Guo $(2005,81)$. Whichever view is taken, any assumption that all these Western mechanical objects were essentially the same misunderstands the way in which the use of clockwork had developed in Europe. By the late eighteenth century, this technology could be found in a wide variety of applications, ranging from the merely entertaining, such as mechanical music and simple automata to advanced scientific instruments, such as chronometers and instruments showing the movement

12 BL IOR, G/12/90, letter from Cathcart to Dundas, August 31, 1787:19-20. 
of astronomical bodies.

These differences lay behind the embassy's choice of presents, which had been carefully selected to avoid being confused with "the mere curiosities sent usually for sale; which, however expensive, or even ingenious, were more glittering than useful." Macartney tried to make this clear to the emperor, explaining that King George had decided that the presents should not be "trifles of momentary curiosity, but little use," but instead, should be "such articles as might denote the progress of science, and of the arts in Europe, and which may convey some idea of information [. . .] or such other articles as might be practically useful." By "trifles of momentary curiosity, but little use," Macartney was referring to ornamental clocks, and apart from not fitting the elevated notions of the embassy, another reason for excluding them was the high cost of the finest examples. As Macartney's deputy later observed, "[i]t would have been vain to think of surpassing, in public presents of this kind, either as to workmanship or cost, what had already been conveyed to China through private channels" (Staunton 1798, 32, 368).

The official presents for the emperor therefore included scientific instrumentsamong them a planetarium, orreries, telescopes, and a pocket chronometer-plus samples of the latest British manufactures. (Macartney also gave the emperor a pair of enameled and diamond-set watches as a personal gift.) Clocks were not entirely ignored, but they were very different from the lavishly jeweled and gilded pieces usually sent to China. In fact, there was just one clock and a matching barometer by the king's clockmaker, Benjamin Vulliamy (1747-1811), ornamented with biscuit porcelain figures in the sophisticated neoclassical taste then fashionable in Europe. ${ }^{13}$ (A smaller pair is now in the Victoria and Albert Museum in London-see Figure 2 for the clock.) Unfortunately, the care taken in choosing these presents and explaining them to the emperor was wasted. Qianlong was either not convinced, or felt unable to acknowledge, that the various articles powered by clockwork such as the planetarium were essentially different from the ornamental clocks with which he was already familiar, and seeing no need for their alleged precision and utility, he dismissed Macartney's assertions as arrogance. ${ }^{14}$

Of course, not all European embassies were so high-minded. Just two years after Macartney reached Beijing, the Dutch embassy led by Isaac Titsingh followed the advice of the Hoppo and other senior Chinese officials in Canton, and gave the emperor a pair of very expensive automaton-clocks. They had been brought to China as a commercial speculation by the commander of the EIC ship accompanying

13 Macartney's Journal (Cranmer-Byng 1962, 96, 99) refers to these as "Vulliamy's clocks," thereby confusing later historians. For Macartney's gift of a pair of watches, see Cranmer-Byng (1962, 123). Other watches were given to court officials.

14 For Qianlong's dismissive attitude to these presents see Zhang (1992). 


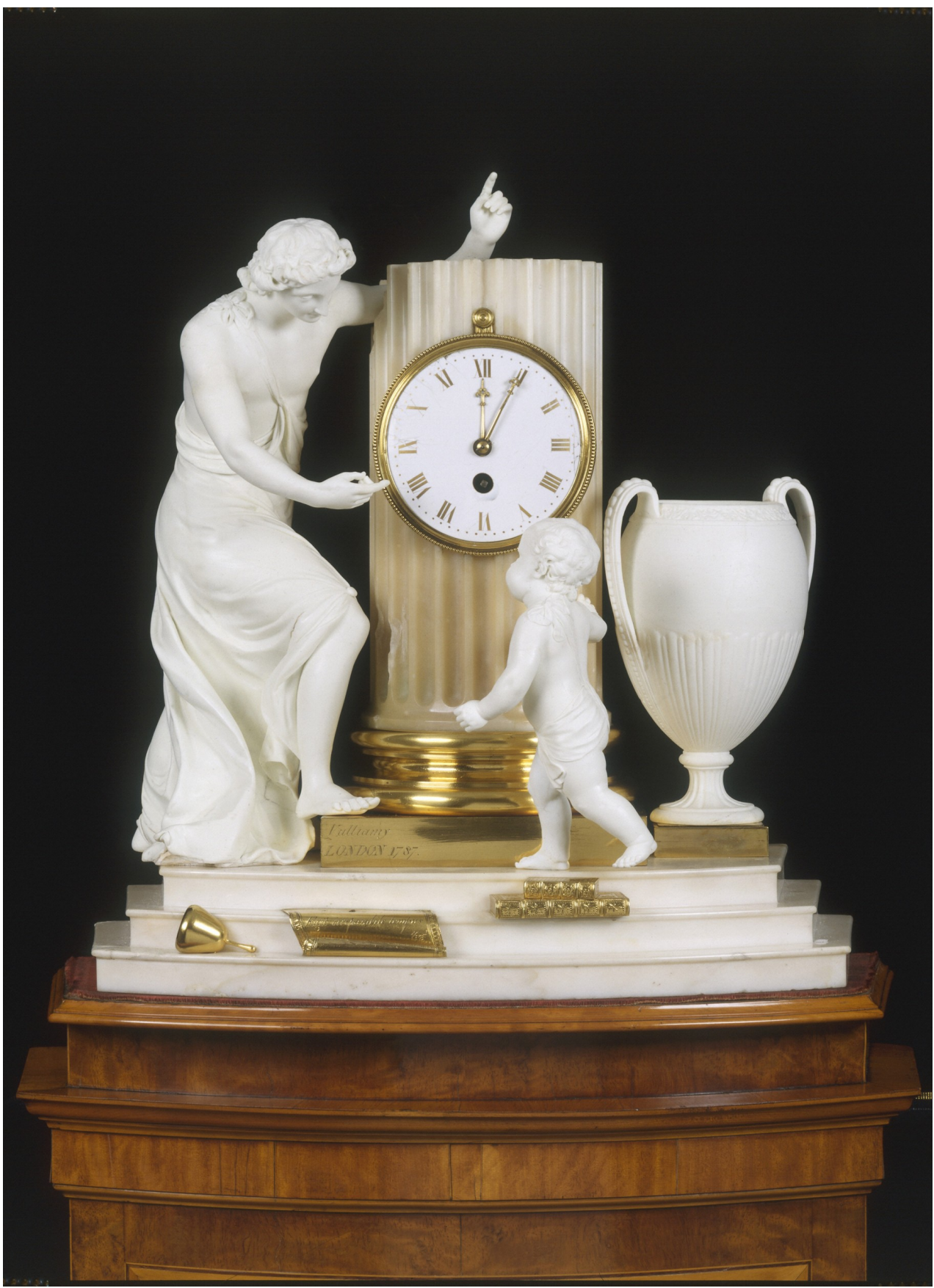

Figure 2: Clock by Benjamin Vulliamy, ca. 1787, with figures in Derby biscuit porcelain. Courtesy of Victoria and Albert Museum, London, W.15:1, 2-1958.

Macartney's embassy, but having been prevented from private trading by Macartney, who did not want the embassy to look like a mere commercial venture, he had left the 
clocks in Canton with Daniel Beale, successor to Cox's son John Henry Cox, who sold them to the Dutch ambassador (Van Braam Houckgeest 1798, 14-15, 19).

Apart from the unusual circumstance that they were taken to Beijing by Europeans, the history of the Dutch embassy's clocks was in fact typical of most of the Western clocks owned by the emperor. Having been brought to Canton as part of the private trade permitted to European ships' officers, the finest were then bought by the Hong merchants on behalf of the Canton customs officials, who sent them to Beijing as part of their annual tribute to the emperor. ${ }^{15}$ It is true that the money to buy these foreign "curiosities" was largely provided by foreign merchants, but their contribution was involuntary, extracted through customs charges and later by the "Consoo" fund levied directly on foreign shipping. Official allocations from these sources for the annual tribute was 50,000 taels (around $£ 17,000$ ) per year in the early years of the century, changing to 30,000 taels $(£ 10,000)$ after 1726 , where it seems to have remained for many years (Cheong 1997, 225). With the establishment of the Consoo fund in the 1780s and the great increase in foreign trade, the allocation for curiosities such as clocks and watches rose to 100,000 taels $(£ 33,000)$ in $1793 / 94$ and even 200,000 taels $(£ 67,000)$ in $1806 / 07$, though it is not clear whether these last amounts were actually spent. ${ }^{16}$

In practice, a large part of the official allocation (estimated at half in 1754) was needed to transport the curiosities to Beijing, and since the remainder was insufficient to pay for everything selected by the officials, including clocks they wished to send to their own superiors, the Hong merchants were forced to supply the clocks at a heavy discount (Morse 1926-1929, 13; Cheong 1997, 226). By the late 1750s, the EIC believed that the Hong merchants received back less than $25 \%$ of the price they had to pay, and they naturally tried to recover their losses by raising the price of tea and other goods sold to the EIC, and attempting to get port charges on foreign ships increased. As a result, the EIC's bulk trade suffered from the private trade of its ships' officers, but the company's periodic attempts to control the trade in clocks and watches had little success owing to the ease with which such articles could be smuggled. The commercial importance of this trade is shown by statements by those engaged in it: James Cox told a parliamentary committee in 1773 that he had, over the past seven years, exported to the East Indies goods worth nearly $£ 750,000$, of which more than two-thirds had been sold (House of Commons Journal 1773, 210). Although the trade in large clocks declined towards the end of the century, a leading firm of London exporters, Magniac \& Beale, was still sending clocks and watches worth $£ 25,000$ per year to Canton at the start of the nineteenth century, while Beale's shop in Canton stocked pieces costing from $£ 1000$ to $£ 5000$ each in 1807 (Greenberg 1951, 78; Renouard de Sainte-Croix 1810, 133-135).

15 For a short account of this trade see Smith (2008).

16 In 1814 the Hong merchants claimed they had to spend $\$ 100,000(£ 25,000)$ annually on such articles. BL IOR, G/12/162:65-67; G/12/189:121-122. 
It will have been noticed that the emperor referred to Macartney as the "Tribute Envoy," and in spite of the embassy's objections, the presents he brought were described in China as tribute. This introduces a further question about the status of these exports. To Europeans, diplomatic presents represented transactions among (legal) equals; but to the Chinese government, familiar with a tributary system of diplomacy with neighboring states, any gifts to the emperor from foreign rulers were simply tribute from inferiors to their superior. There was a similar cultural misunderstanding about the role of the clocks and other curiosities sent from Canton to Beijing. These were seen by Europeans as bribes paid by Chinese officials or merchants to obtain favors - a practice that certainly existed, though it was officially banned. However, the regular consignments of such goods, such as the annual tribute sent to the emperor and senior officials, were officially sanctioned as a way in which officials in Canton shared the benefits of their posts with their sponsors, and through which the emperor himself could share in the prosperity produced by foreign trade.

\section{Conclusion}

It is understandable that producers such as James Cox were tempted to generate publicity with exaggerated claims about their clocks being given by European rulers and great trading companies to the emperor of China and other Asian rulers. They were probably aware that clocks had historically been used in that way, and they knew that their own clocks might become gifts to the emperor or important officials once they reached China. However, it is important for modern scholars to understand the real history of these clocks, and not just for the study of commercial and diplomatic relations between China and Europe. It is also essential for a proper appreciation of the clocks themselves. Knowing that they were made as trade goods and not specially commissioned by wealthy patrons makes it easier to understand why such clocks survive in relatively large numbers and a wide range of types and quality. This is not the place to discuss individual clocks, but commercial pressure for economy and ease of manufacture can often be detected in a maker's use of standardized modules that can be assembled in different ways to produce clocks of different size. Standardization also appears in the use of similar cases by different makers; for example, two impressive clocks now in the Palace Museum have closely related "horse and tent" superstructures probably from the same supplier, but one is signed by James Cox and the other by Stephen Rimbault. Once they are recognized to be trade goods, it also becomes less surprising to find that the "gold" cases and ornaments of many clocks are gilded base metal, and the "gemstones" ornamenting them are usually just colored glass. Similar economies can be seen in their mechanisms, which are often standard clock and musical movements adapted to fit oddly shaped cases, and sometimes to do a rather different job. 
An awareness of the private, commercial origins of these clocks should not be allowed to diminish their significance. On the contrary, it may seem even more remarkable that, without the financial support of the state or major corporations, and simply in response to market demand, the manufacturing and trading systems of eighteenth-century London were able to produce such extraordinary objects and export them to the other side of the globe. Once there, many would indeed become the treasured possessions of the emperor of China, but as tribute from his own subjects and not as presents from the West.

\section{References}

Anonymous. 1772a. "Piece the Fifteenth." In A Descriptive Catalogue [. . .] in Mr. Cox's Museum, at Spring Gardens. London.

Anonymous. 1772b. "Public Ledger, April 11." In Collection of Extracts from the London Publications Relative to the Museum in Spring Gardens. Pamphlet 6456:28-32. London: London Guildhall Library.

Blancard, P. 1806. Manuel du commerce des Indes Orientales et de la Chine [. . .]. Paris.

Bonnant, G. 1960. “The Introduction of Western Horology in China.” La Suisse Horlogère 1:32.

Cheong, W. E. 1997. The Hong Merchants of Canton: Chinese Merchants in Sino-Western Trade. Richmond, Surrey: Curzon.

Cox, J. 1775. The Arrangement, Allotment, and Particular Description of the Several Prizes, in the Museum Lottery. London.

Cranmer-Byng, J. L., ed. 1962. An Embassy to China: Lord Macartney's Journal 1793-4. London: Longmans, Green \& Co.

Daily Advertiser. 1731. December 1, 1731.

Greenberg, M. 1951. British Trade and the Opening of China 1800-1842. Cambridge: Cambridge University Press.

Harcourt-Smith, S. 1933. A Catalogue of Various Clocks [. . .] in the Palace Museum and the Wu Ying Tien, Peiping. Beijing: The Palace Museum.

House of Commons Journal. 1773. Vol. 34, March 19, 1773.

Jamieson, G. 1883. “The Tributary Nations of China." China Review 12 (2): 94-109. (This article draws on Chinese sources.)

London Evening Post. 1766. December 6-9, 1766. New York: Metropolitan Museum [accession number 1982.60.137].

Morse, H. B. 1926-1929. Vol. 5 of Chronicles of the East India Company Trading to China 1635-1834. Oxford: Clarendon Press.

Pagani, C. 2001. Eastern Magnificence and European Ingenuity: Clocks of Late Imperial China. Ann Arbor: University of Michigan Press.

Pelliot, P., ed. 1920-1921. "Letter from Father Chalier, Jesuit Supervisor of the Imperial Clock Workshop." Dated October 16, 1736. T'oung Pao 20 (1): 64-67. Leiden: Brill.

Renouard de Sainte-Croix, F. 1810. Tome 3 of Voyage Commercial et Politique aux Indes Orientales [...] 1803-1807. Paris. 
Singer, A. 1992. The Lion and the Dragon. London: Barrie and Jenkins.

Smith, R. 2000. "James Cox (c. 1723-1800): A Revised Biography." The Burlington Magazine 142 (1167): 353-361.

Smith, R. 2008. "The Sing-Song Trade: Exporting Clocks to China in the Eighteenth Century." Antiquarian Horology 30 (5): 629-658.

Staunton, G. 1798. Vol. 1 of An Authentic Account of an Embassy [. . .] to the Emperor of China. Dublin.

Van Braam Houckgeest, A. E. 1798. Vol. 1 of An Authentic Account of the Embassy of the Dutch East India Company [. . . ]. London.

Whitehall Evening Post. 1769. February 9-11, 1769.

Zhang, Pu, and Guo Fuxiang. 2005. L'art de l'horlogerie occidentale et la Chine. Beijing: China Intercontinental Press.

Zhang, Shunhong. 1992. "Historical Anachronism: The Qing Court's Perception of and Reaction to the Macartney Embassy." In Ritual and Diplomacy. The Macartney Mission to China 1792-1794, edited by R. A. Bickers, 34-36. London: The Wellsweep Press. 